Journal of Educational Method and Technology Vol. 2 No. 2, Agustus 2019

P-ISSN 2622-8459 E-ISSN 2622-8467

http://ejournal.unima.ac.id/index.php/jemtec

\title{
A Study Of Work Ethic And Commitment Of Professional Teachers Advisor at SMA Negeri Kota Manado (2018)
}

\author{
Y Taher ${ }^{1}$ \\ ${ }^{1}$ Universitas Negeri Manado, Indonesia \\ corresponding author: 1'yasintaher@unima.ac.id
}

\begin{abstract}
The purpose of this research are: 1) to know work ethics counselor from the aspect of implementation of tasks SMA service in Manado City. 2) To know the effort / how to tutor students develop ethics and morals in SMA Negeri Manado. 3) To know professional commitment counselor in the running task in this school. 4) To determine the factors that inhibit a tutor increase work ethic and professional commitments. 5) To know the efforts have been made by a professionals tutor to overcome barriers to the implementation of the ministry in SMA Negeri of Manado City. This research uses qualitative approach. The sampling technique used is purposive sampling and snowball sampling. The main instrument in qualitative research is that the researchers themselves in the data collection are: 1). Observation 2). Interview, .3). Documentation. Data analysis technique used qualitative analytical technique. Teacher of professional counsellor to overcome barriers to the implementation of the ministry in SMA Negeri Manado? "According to the informant that the effort to overcome the implementation of the ministry in SMA Negeri in Manado City is still limited, namely seminars relating to the program counselling, either at regional and national level. Based on the results of the research and the discussion outlined above, it can be concluded that the work ethic and professional commitment of senior high school mentor teachers are in the category of enough, and who are still low, and each school has a Different obstacles.
\end{abstract}

Keywords: Work Ethic; Commitment; Supervisor; professional.

\section{Introduction}

Humans need education in life. Education is a business so that people can develop their potential through a learning process and or other means which are known and recognized by the public. Confirmed if Shane (2009), that education is to contribute to a culture in store tomorrow. In the context of teacher professional whose existence determines the level of mobility of people and nations in the global cultural stage, then the holders of the teaching profession must also dynamically respond and anticipate external dynamics. Therefore, upgrading professional skills of teachers may also be interpreted as an effort to help teachers who have not professional become a professional (Bafadal, Ibrahim, Improving Teacher Professionalism (Jakarta: Earth Literacy, 2006), p. 66. Various efforts to improve the quality of teachers is always done by the government, one of which is through the teacher certification program. But the fact that found that teacher certification 
program turns out there are not as expected the community, because there are teachers who have passed the certification is not yet show the expected quality. One of the problems is the "work ethic and professional commitment of teachers remains low, including a guidance counselor at SMA Negeri Manado. Ethos shaped by customs, cultural influences, as well as the value system he believed. This ethos of the word, also known as the word ethics, etiquette is almost close to the definition of morals or values associated with the bad good (moral), so that in the ethos of passion or enthusiasm contained powerful to grind optimally, better and even strive to achieve quality work as perfectly as possible. And of other restrictions mentioned that ethos means the characteristic, trait or habit, customs, or even moral tendency of way of life of a person, a group or a nation (Mochtar Buchori, 1994). The commitment of teachers is a self attachment to the duties and obligations as a teacher who can bear responsibility and responsiveness and innovative development of science and technology. The value of commitment to the task or job in this respect are the values of work. For that teacher professional teachers appear to be more enterprising and eager to do the job. Professional tutor who will carry out their duties effectively. To be able to carry out tasks in a professional manner required a variety of requirements such as 4 competence, personal maturity, attitude, dedication, and must have a high commitment. With a high level of commitment of the teacher education are expected to be more ready and capable to face all kinds of challenges and obstacles. In is committed to being a professional teacher would seem characteristic or characteristics such as teachers; high attention to the students, amount of time and energy spent, work as much for others In is committed to being a professional teacher would seem characteristic or characteristics such as teachers; high attention to the students, amount of time and energy spent, work as much for others In is committed to being a professional teacher would seem characteristic or characteristics such as teachers; high attention to the students, amount of time and energy spent, work as much for others,

Park (in Sahertian, 1994) stated that the commitment of teachers is an inner strength that comes from within the heart of a teacher and a force from outside itself about its work that could give a major influence on the attitudes of teachers in the form of responsibility and responsiveness (inavotif) the development of science and technology. Broader commitment of concern, because in terms of commitments covered the sense of effort and encouragement as well as considerable time.

Mulyasa (2003) found independently commitment needs to be built on each individual school community, including teachers mentors, especially to eliminate the setting of bureaucratic rigidity of thought and culture, such instructions must wait boss by turning it into a creative and innovative thinking.

Based on the above it can be concluded that the commitment professional tutor is a self attachment to the duties and obligations as a teacher who can bear responsibility and responsive and innovative attitude towards the development of science and technology. So in that commitment, there are several elements among others, the ability to understand themselves and their duties, radiant inner attitude, (inner strength) power from outside and responsive to change. The elements gives rise to responsibility to the duties and obligations of a person who committed so that the task is done with full sincerity. This study aims: a. To know the work ethic of the aspects of the implementation guidance counselor at SMA service tasks Manado. $b$. 
Journal of Educational Method and Technology Vol. 2 No. 2, Agustus 2019

P-ISSN 2622-8459 E-ISSN 2622-8467

http://ejournal.unima.ac.id/index.php/jemtec

To know the effort / how to tutor students develop ethics and morals in SMA Negeri Manado. c. To know the professional commitment of teachers mentors in performing their duties at school. d. To determine the factors that hinder the tutor improve work ethics and professional commitments e. To know efforts have been made by a professional tutor to overcome barriers to the implementation of the ministry in high school

\section{Research Method}

This study used a qualitative approach. The subject of the research that a key informant (primary) is the supervising teacher and students of SMA Negeri Manado. While the secondary informants are principals and teachers for study in SMA Negeri Manado. Sampling technique used is purposive sampling and snowball sampling . The main instrument in qualitative research is the researcher himself in data collection guided by an interview guidelines (developed out of focus) with tools such as the recorder (tape recorder), a photo camera and stationery used in the data collection process. While the techniques used in data collection are: 1). Observation, 2 ). Interviews, 3). Documentation, namely copy / copy and learn the formal provisions, archives, official records relating to the focus of research. Analisisis engineering data using qualitative analysis techniques.

\section{Results and Discussion}

\section{Research}

1) Main Problem; How the work ethic of a professional counselor implementation aspects of ministry in SMA Negeri Manado?

Based on the narrative of the informants that the work ethic of a professional guidance counselor at SMA Negeri Manado, uneven; Nothing good, quite good and there is a low work ethic. Explained away by these informants that teachers who have a high work ethic shows the quality of work, in order to obtain various achievements that benefit themselves, students, and community. He worked earnestly danbertanggung responsible. While the low teacher's work ethic is not responsible for duties.

2) Second Problem; How can a professional guidance counselor attempts to develop ethical and moral high school students in Negeri Manado?

According expert informant that the main target in guidance and counseling program in schools is to develop students' ethical and moral. This task is not easy, due to the global development of mental affect students, the counselor should have a good work ethic, so it is always keen to provide the direction and guidance to the students patiently. A professional guidance counselor must own a skill, ability, and confidence, as well as the needed elements of quality leadership that can provide encouragement, encouragement, guidance, and support to subordinates, and supported with adequate facilities.

3) Third Problem; How professional commitment tutor in performing their duties at this school?

Based on the narrative informants that commitment is a self attachment to the duties and obligations as a teacher who can bear responsibility and responsiveness and innovative development of science and technology. The value of commitment to the task or job in this respect are the values of work. 
Journal of Educational Method and Technology Vol. 2 No. 2, Agustus 2019

P-ISSN 2622-8459 E-ISSN 2622-8467

http://ejournal.unima.ac.id/index.php/jemtec

For that teacher professional teachers appear to be more enterprising and eager to do the job. Instead of teachers who do not have professional commitments always indifferent to their duties, less responsive and innovative in order to achieve optimal results. They often neglect and less concerned about the problems faced by students.

From the narrative that informants can be interpreted that a professional counselor teacher at SMA Negeri Manado there that do not have a professional commitment to the profession.

4) Fourth Problem; What factors impede teacher advisers to improve their work ethic and professional commitment?

According to the informant that the real obstacle tutor to improve the ethic work and professional commitments main thing is mentally every personnel itself, including the skills, abilities, and confidence, and leadership are lacking spirit and motivation, as well as the facility is not adequate. while the low commitment, because generally a tutor, has the settings bureaucratic rigidity of thought and culture, such instructions must wait boss by turning it into a creative and innovative thinking. For professional guidance counselor commitment is a self attachment to the duties and obligations as a teacher who can bear responsibility and responsive and innovative attitude towards the development of science and technology. So in that commitment, there are several elements among others, the ability to understand themselves and their duties, radiant inner attitude, the strength of the outer and responsive to change. The elements gives rise to responsibility to the duties and obligations of a person who committed so that the task is done with full sincerity.

Based on the above narrative of the informant can be interpreted that include skills, abilities, and confidence, and leadership are lacking spirit and motivation, as well as facilities that do not memadai. Sedangkan low commitment, because generally a tutor, has the settings bureaucratic rigidity of thought and culture, such user must wait for the boss to turn it into a creative and innovative thinking.

5) Principal fifth problem; "The efforts of what has been done by a professional tutor to overcome implementation barriers SMA ministry in Manado?"

According to the informant that the attempt to overcome implementation barriers SMA ministry in the city of Manado is still limited, seminars related to guidance and counseling programs, both at regional and national level. In addition another problem was the personnel supervising teacher assigned tasks other than prefesinya, so the main task is often overlooked, it is associated with a management system that does not understand to the guidance and counseling program, and there are also personnel supervising teacher who does not have Besik in the field of Guidance and Counseling, Actually inhibiting factors tutor for meningkan professional work ethic and commitment to the main one is mentally every personnel itself, includes the skills, abilities, and confidence, and leadership are lacking spirit and motivation, as well as facilities that do not adequate. Meanwhile the low commitment, because usually a tutor, has the settings bureaucratic rigidity of thought and culture, such instructions must wait boss by turning it into a creative and innovative thinking. For professional counsellor commitment is 
Journal of Educational Method and Technology Vol. 2 No. 2, Agustus 2019

P-ISSN 2622-8459 E-ISSN 2622-8467

http://ejournal.unima.ac.id/index.php/jemtec

a self attachment to the duties and obligations as a teacher who can bear responsibility and responsive and innovative attitude towards the development of science and technology. So in that commitment, there are several elements among others, the ability to understand themselves and their duties, radiant inner attitude, the strength of the outer and responsive to change. The elements gives rise to responsibility to the duties and obligations of a person who committed so that the task is done with full sincerity.

\section{Results of Discussion}

Observing the narrative of the informant above can be interpreted that the factor of skill, ability, and confidence, and leadership are lacking spirit and motivation, as well as facilities that do not adequate. Mean while a low commitment, because generally counselor, thought and culture has the settings that bureaucratic rigidity, such as having to wait hint boss by turning it into a creative and innovative thinking,

For professional counselor commitment is a self attachment to the duties and obligations as a teacher who can bear responsibility and responsive and innovative attitude towards the development of science and technology. So in that commitment, there are several elements among others, the ability to understand themselves and their duties, radiant inner attitude, the strength of the outer and responsive to change. The elements gives rise to responsibility to the duties and obligations of a person who committed so that the task is done with full sincerity and responsibility.

Professional counselor should have a high commitment, because the commitment is a self attachment to the duties and obligations as a teacher who can bear responsibility and responsive and innovative attitude towards the development of science and technology. So in that commitment, there are several elements among others, the ability to understand themselves and their duties, radiant inner attitude, the strength of the outer and responsive to change. The elements gives rise to responsibility to the duties and obligations of a person who committed so that tasks are carried out properly. Good job commitment constituted with a high work ethic, the work ethic of factors largely determine one's commitment,

While the factors that can decrease work ethic counselor according to William B. Cester (in Whjo Sumidjo, 2002) including; gap, the award is not effective, the absence of authority, supervision is not balanced, the career is not flexible, the injustice of assignment and promotion opportunities

Park (in Sahertian, 1994) stated that the commitment of teachers is an inner strength that comes from within the heart of a teacher and a force from outside itself about its work that could give a major influence on the attitudes of teachers in the form of responsibility and responsiveness (innovative) the development of science and technology. Broader commitment of concern, because in terms of commitments covered the sense of effort and encouragement as well as considerable time.

\section{Conclusions And Suggestions \\ Conclusion}

Based on the results of research and discussion outlined above, it can be concluded that the work ethic and professional commitment of Manado State High 
Journal of Educational Method and Technology Vol. 2 No. 2, Agustus 2019

P-ISSN 2622-8459 E-ISSN 2622-8467

http://ejournal.unima.ac.id/index.php/jemtec

School guidance counselor there in enough categories, and which is still low, and each school has different obstacles.

\section{Suggestion:}

a. Expected education department more selective in hiring teachers professional counselor with regard counseling educational background.

b. It is expected that the education department pay attention to the welfare of the counselor teacher.

c. Each school principal is not expected to provide additional task which imposes a fundamental duty supervising teacher.

d. It is expected that school inspectors, particularly supervisors supervising teachers more productive in performing their duties and at the same time can provide a solution to enable teachers to develop themselves and to correct his mistakes.

e. Facilities of individual and group counseling room is adequate, such as; tables, chairs and cabinets of data storage, and others.

\section{References}

Biggs, Donald A. \& Blocher H. 1986. The Cognitive Approach To Ethical Counseling: Values in Counseling Ethic. New York: State University of New York at Albany.

Blocher, DH1988. The Professional Counselor.New York: McMillan Publishing Company.

Chiko, CH et al. 1980. A Model to Systematize Competencies in Counselor Education. Counselor Education and Supervision. 19. 283-291.

Bogdan, RC \& Biklen, SK 1998. Qualitative Researh for Eduication: An Introduction to Theory and MethodsBoston: Allyn and Bacon, Inc.

Cahyoto, 2002. Budi Character in the Perspective of Education. Malang: DepdiknasDirector General of Basic Education and Teacher Upgrading Center IPS middle- and PMP Poor

Faisal, Sanapiah. 1990. Qualitative Research: Fundamentals and aplikasiu, Malang: YA3.

Juntika, Syamsu, Joseph. 2007. The foundation of Guidance and Counseling. Bandung: Rosda

Moleong, LJ 1988. Qualitative Research Methodology, Bandung: Teens

Paul, Suparno. Budi 2002. Character Education in Schools An Overview. Yogyakarta: Canisius

Prayitno ,. 1999. Counseling Services in Schools. Jakarta: Ghalia

Rochman Natawidjaja. Competence and Ethics Counselor 2003. Future, Papers Seminar and Workshop on 17 February 2003, Bandung: Program Pascasarjana

Sahertian. 1994. Profile of Professional Educators. Yogyakarta: Andi Offset.

Siagian, SP 2004. Human Resource Management. Jakarta: Earth Literacy

Sinamo, Jansen. 2005. Eight Professional Work Ethic: Navigator You Go

Success. Graphic Mardi Yuana, Bogor.

Shertzer, B. \& Stone, SC1981. Fundamentals of Guidance. Boston: Houghton Mifflin Company 
Journal of Educational Method and Technology Vol. 2 No. 2, Agustus 2019

P-ISSN 2622-8459 E-ISSN 2622-8467

http://ejournal.unima.ac.id/index.php/jemtec

Subino, H. 1988. Principles of Data Collection Data Analysis and Interpretation, and Rekomendai In Qualitative Research. Bandung: Teachers' Training 